Bangladesh J. Bot. 44(4): 581-589, 2015 (December)

\title{
GENETIC VARIABILITY TO IMPROVE YIELD AND RESISTANCE TO BACTERIAL LEAF BLIGHT IN RICE
}

\author{
Ak Singh*, Rk Singh, Sunil Kumar, M Arya And Pk Singh \\ Department of Genetics and Plant Breeding, Institute of Agricultural Sciences, \\ Banaras Hindu University, Varanasi-221005, India
}

Key words: Correlation, Disease severity, Gene number, Heritability, Grain yield

\begin{abstract}
One hundred $F_{2}$ and $F_{3}$ single plant progenies along with their parents and the infector rows were evaluated for 13 quantitative traits to assess the genetic variability, heritability, associations and estimation of number of genes for bacterial leaf blight resistance and yield related traits. In both $F_{2}$ and $F_{3}$, a wide range of variability was present for all the traits, indicating considerable scope for selection. High heritability accompanied with high genetic advance was observed for plant height, panicle length, panicle weight, number of effective tillers per plant and grain yield per plant. Positive and significant correlation were observed between grain yield per plant with days to 50\% flowering, plant height, panicle length, panicle weight, number of effective tillers per plant, test weight and flag leaf length in either one of the generation or in combination of both $\mathrm{F}_{2}$ and $\mathrm{F}_{3}$. Path-coefficients analysis showed that plant height, panicle length and test weight had high direct positive effect in both the $F_{2}$ and $F_{3}$. The estimated number of gene(s) in the segregating generations for bacterial leaf blight was 2.14 in the $F_{2}$ and 0.92 in the $F_{3}$ revealed that two genes were involved in the inheritance of resistance to bacterial leaf blight in $F_{2}$, while only one gene in $F_{3}$ due to dominance effect.
\end{abstract}

\section{Introduction}

Rice (Oryza sativa L.) is one of the oldest domesticated crops provides food for more than half of the world's population and constitutes a major source of calories for urban and rural inhabitants (Khush 2005). Bacterial leaf blight caused by Xanthomonas oryzae pv. oryzae (Xoo) is one of the most devastating diseases affecting entire rice acreage. It causes severe yield losses of up to $80 \%$, depending on the stage of the crop, cultivar susceptibility and the environmental conditions (Srinivasan and Gnanamanickam 2005).

Crop improvement for grain yield has been achieved in rice through effective use of $F_{2}$ and $F_{3}$ segregating populations and fixing desirable traits combinations. However, there are still possibilities to increase the yield output through proper breeding technologies. Grain yield is a complex trait and is the result of interaction of many variables. The existence of correlation may be attributed to the presence of linkage or pleiotropic effect of genes or physiological and development relationship or environmental effect or in combination of all (Oad et al. 2002). The importance of correlation and path coefficient analysis is particularly appreciable when highly heritable characters associated with a complex trait like yield are identified, and successfully used as criteria for effective selection to achieve high yield. To accumulate yield contributing characters together with bacterial blight resistance, it is essential to know the association among various traits along with path coefficients between the major contributors and the target trait. Therefore, the present investigation was undertaken to study the variability, heritability, associations and estimation of number of genes for bacterial leaf blight resistance and yield related traits in the segregating $\mathrm{F}_{2}$ and $\mathrm{F}_{3}$; and possible breeding strategies to improve yield with enhanced resistance are discussed.

*Author for correspondence: <anilbhu987@gmail.com>. 


\section{Material and Methods}

$\mathrm{F}_{2}$ and $\mathrm{F}_{3}$ single plant progenies derived from a cross between two indica rice varieties i.e., HUR 105 (bacterial leaf blight susceptible parent) and IRBB 55 (bacterial leaf blight resistant parent) were used. The $100 \mathrm{~F}_{2}$ and $\mathrm{F}_{3}$ single plant progenies were raised along with their parents and infector rows of susceptible varieties Pusa Basmati 1 (PB 1) in a CRBD during Kharif 2013 at Agricultural Research Farm, Institute of Agricultural Sciences, Banaras Hindu University, Varanasi, India. Each of the $\mathrm{F}_{2}$ and $\mathrm{F}_{3}$ lines was grown in three rows of $1.5 \mathrm{~m}$ in three replications. Spacing was maintained at $20 \mathrm{~cm}$ between rows and $15 \mathrm{~cm}$ between plants. The recommended packages of practices were followed to raise healthy crops.

The culture of Xanthomonas oryzae pv. oryzae (strain BX043 wild type) was obtained from Directorate of Rice Research, Hyderabad, India and subcultured on peptone sucrose agar medium and maintained it at pH $7.2-7.4$ (Fahy and Persley 1983) and pathogenicity test, clipping method was used to inoculation the rice plants with Xanthomonas oryzae pv. oryzae. The test was conducted on fully developed leaves at 45-day-old-rice plants after transplanting. The top 1 - 3 inches of completely developed leaves was clipped off one by one with sterilised scissors dipped in a bacterial suspension containing $10^{8} \mathrm{cfu} / \mathrm{ml}$. Following inoculation, the plants were observed after every 24 hrs time intervals to note the appearance of disease symptoms, and lesion length were recorded at 14, 21 and 28 days after inoculation (DAI).

After eliminating the border plants, observations were recorded on ten randomly selected plants from the parents and the $\mathrm{F}_{2}$ and $\mathrm{F}_{3}$ single plant progenies from each replication on days to $50 \%$ flowering (DF), days to maturity (DM), plant height (PH), panicle length (PL), panicle weight (PW), number of effective tillers per plant (ET), fertile spikelet per panicle (FSP), total number of spikelet per panicle (TSP), test weight (TW), grain yield per plant (GYP), flag leaf length (FLL), flag leaf width (FLW) and disease severity (DS), and mean value were used for statistical analysis.

The data were analysed for variability as per procedure given by Panse and Sukhatme (1985), correlation coefficient by Al-Jibouri et al. (1958) and path analysis by Dewey and Lu (1959). The regression analysis was performed to detect association between resistance to bacterial leaf blight and quantitative traits using SPSS 16.0 version software. Per cent disease incidence was calculated with the help of formula given by Gnanamanickam et al. (1999).

The gene number or effective factors in the $\mathrm{F}_{2}$ and $\mathrm{F}_{3}$ segregating population was estimated following Bjarko and Line (1988) as, $\mathrm{n}=(\mathrm{GR})^{2}[1.5-2 \mathrm{~h}(1-\mathrm{h})] / 8\left[V_{\mathrm{F} 2}-\left(V_{\mathrm{PS}}+V_{\mathrm{PR}}+2 V_{\mathrm{F} 1}\right) / 4\right]$ and $\mathrm{n}=(\mathrm{GR})^{2} / 5.33\left[V_{\mathrm{F} 3}-\left(V_{\mathrm{PR}}+V_{\mathrm{PS}}\right) / 2\right]$, respectively. Where $\mathrm{n}=$ estimated number of segregating genes, $\mathrm{GR}=$ genotypic range, estimated as per phenotypic range of the segregating generation or the difference between the two parents $\left(P_{S}-P_{R}\right), P_{R}=$ the mean of the resistant parent, $P_{S}=$ the mean of the susceptible parent, $h=\left(F_{1}-P_{R}\right) /\left(P_{S}-P_{R}\right), F_{1}=$ the mean of the $F_{1}$ generation, $V_{\mathrm{PR}}=$ the variance of the resistant parent, $V_{\mathrm{PS}}=$ the variance of the susceptible parent, $V_{\mathrm{F} 1}=$ the variance of the $\mathrm{F}_{1}$ generation, $V_{\mathrm{F} 2}=$ the variance of the $\mathrm{F}_{2}$ generation, $V_{\mathrm{F} 3}=$ the variance of the $\mathrm{F}_{3}$ generation and $\mathrm{n}=$ the estimated number of segregating genes.

\section{Results and Discussion}

All the traits showed wide range of variation in both the segregating $F_{2}$ and $F_{3}$ indicating ample scope for selection (Table 1). The magnitude of phenotypic coefficient of variance was higher than corresponding genotypic coefficient of variances. As expected, the genotypic coefficient of variances for panicle length, panicle weight, fertile spikelet per panicle, total number of spikelet per panicle, test weight, flag leaf length and flag leaf width in $\mathrm{F}_{3}$ were lower than the $F_{2}$, which is obviously due to increase in homozygosity of alleles in the $F_{3}$ arising through the 


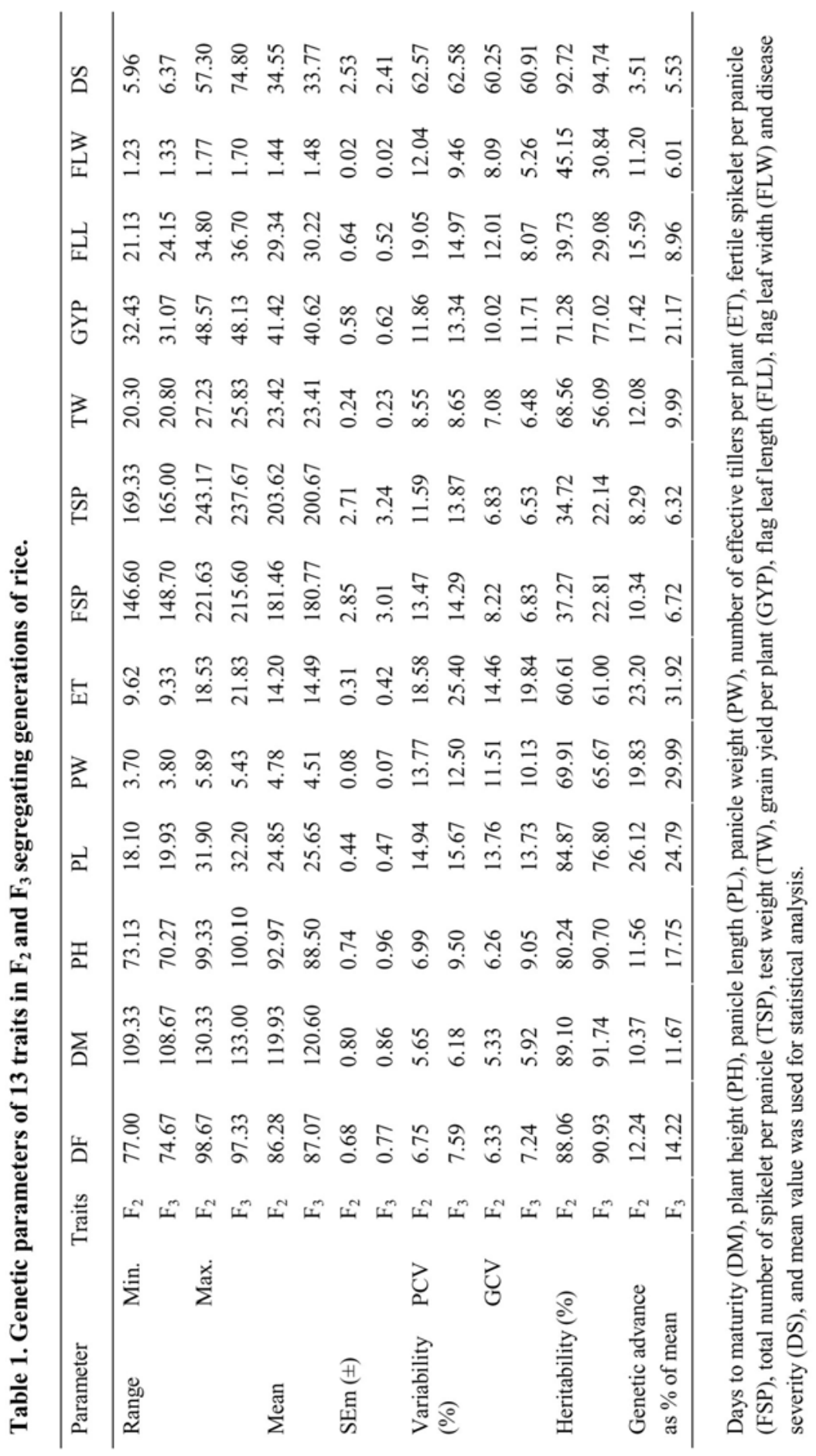


fixation of genes in these traits, while higher genotypic coefficient of variances in $F_{3}$ the $F_{2}$ for days to $50 \%$ flowering, days to maturity, plant height, number of effective tillers per plant, grain yield per plant and disease severity. The phenotypic coefficient of variance of days to $50 \%$ flowering, days to maturity, plant height, panicle length, number of effective tillers per plant, fertile spikelet per panicle, total number of spikelet per panicle, test weight and grain yield per plant was higher in $F_{3}$ than the $F_{2}$. Results of present study support the earlier observations (Chouhan et al. 2014, Singh et al. 2014a), though their studies were limited to pure lines.

The extent to which genetic segregation is expected in the later generation of a cross is largely a reflection of the heritability of the traits. Here, the parents and progenies were evaluated in the same season to avoid over or under estimation of heritability arising out of possible environmental factors i.e., season $\times$ generation interaction. The high heritability was observed for days to 50 per cent flowering, days to maturity, plant height, panicle length, panicle weight, number of effective tillers per plant, test weight, grain yield per plant and disease severity. High heritability does not always indicate high genetic gain. The heritability coupled with high genetic advance as per cent of mean under the control of additive gene action would be effective for selecting superior lines. High heritability coupled with high genetic advance as per cent of mean were recorded for panicle length, panicle weight, number of effective tillers per plant and grain yield per plant, while high heritability coupled with low genetic advance as per cent mean were observed in disease severity. Variability of these traits could be predominantly due to additive gene effects, so the phenotypic selection would be effective. The traits days to $50 \%$ flowering, days to maturity, plant height, test weight, flag leaf length and flag leaf width exhibited high heritably with moderate genetic advance, which is desirable. Similarly, high heritability and genetic advance as per cent of mean was earlier reported by Singh et al. (2013) in total number of grains per panicle, filled grains per panicle, number of effective tillers per plant, leaf width and grain yield per plant.

The phenotypic correlation coefficients were positive and highly significant between grain yield per plant with days to $50 \%$ flowering, plant height, panicle length, panicle weight, number of effective tillers per plant, test weight and flag leaf length in either one of the generations or in combination of both generations (Table 2). The association studied indicated that the grain yield of rice can be improved by selecting lines having higher performance for these traits. Similar trend was observed in the earlier findings (Singh et al. 2014b) for plant height, panicle length, fertile spikelet per panicle, total grains per panicle, spikelet fertility percentage and test weight, although their studies were based on pure lines. In both the $\mathrm{F}_{2}$ and $\mathrm{F}_{3}$, the association of grain yield per plant with disease severity was positive and very low though non-significant. The correlation between disease severity and days to $50 \%$ flowering, days to maturity, plant height, panicle length, number of effective tillers per plant and flag leaf width was positive non-significant. The association between disease severity and panicle weight, fertile spikelet per panicle, total number of spikelet per panicle, test weight and flag leaf length was negative and non-significant. Most of the above results of present investigation are in conformity with the finding of Loan et al. (2004).

The results of regression analysis are presented in Table 3. The positive and significant regression in $\mathrm{F}_{2}$ and $\mathrm{F}_{3}$ were observed for plant height and flag leaf width. In $\mathrm{F}_{2}$, positive and significant regression was observed for panicle length and test weight while negative nonsignificant for number of effective tillers per plant, grain yield per plant and flag leaf length. In $\mathrm{F}_{3}$ positive and significant regression was observed for grain yield per plant and flag leaf length while negative and significant for test weight. When positive and significant regression of the above traits are taken into consideration, positive selection level was found to be suitable for effective selection of desirable segregants in both generations. In the present study, regression analysis suggested that the traits plant height, panicle length, test weight, grain yield per plant, flag leaf length and flag leaf width contributed to bacterial leaf blight resistance in either one of the 


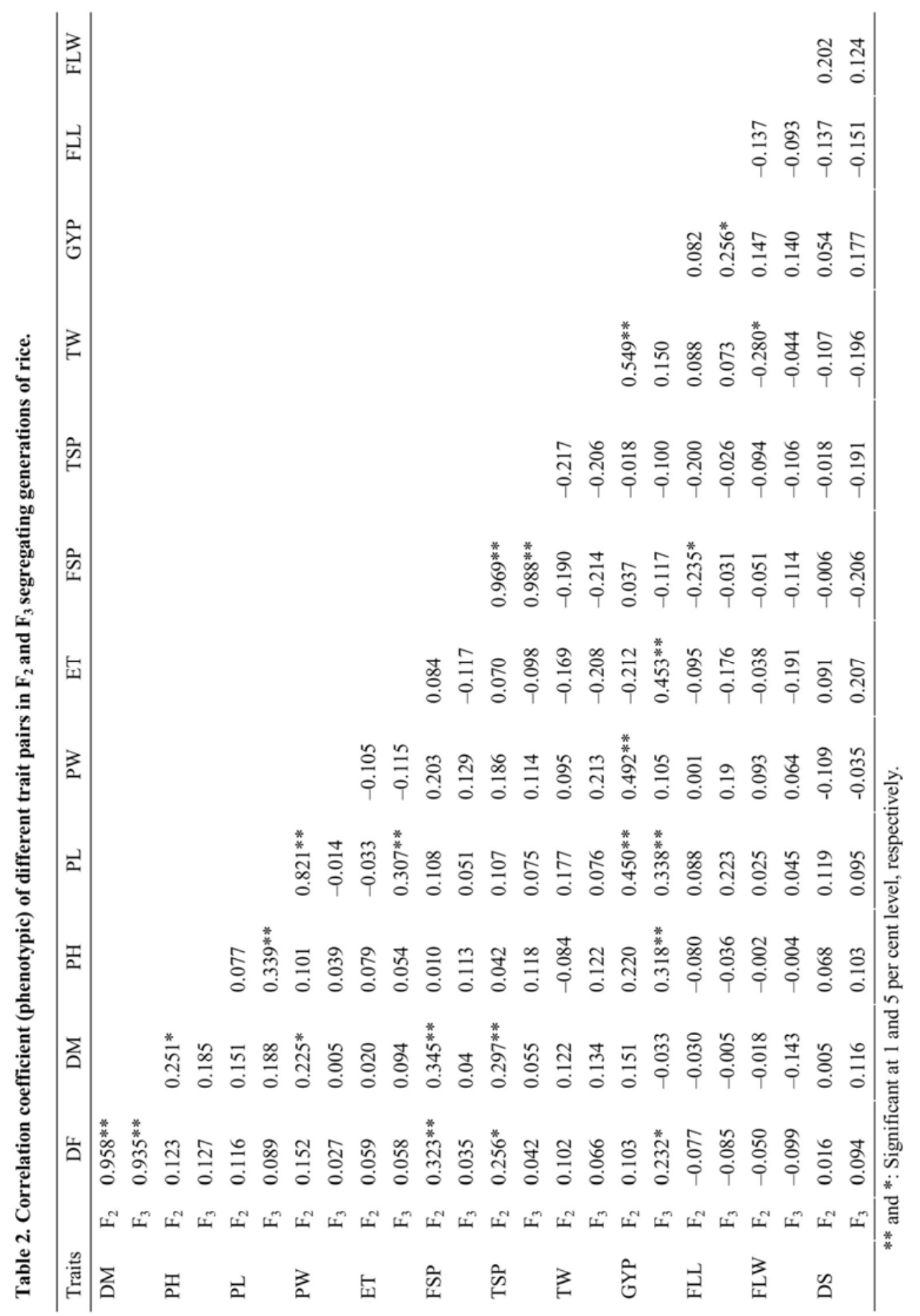


generation $\left(\mathrm{F}_{2}\right.$ or $\left.\mathrm{F}_{3}\right)$ or in combination of both generation. Similarly, Channamallikarjuna et al. (2010) reported that plant height and leaf length were contributed to disease resistance in rice.

Table 3. Regression analysis for bacterial leaf blight resistance to other yield traits in rice.

\begin{tabular}{|c|c|c|c|c|c|c|}
\hline \multirow[t]{2}{*}{ Traits } & & \multicolumn{2}{|c|}{$\begin{array}{l}\text { Unstandardized } \\
\text { coefficient }\end{array}$} & \multirow[t]{2}{*}{$\begin{array}{c}\text { Standardized } \\
\text { coefficient }\end{array}$} & \multirow[t]{2}{*}{$\mathrm{t}$ value } & \multirow[t]{2}{*}{$p$ values } \\
\hline & & B & SE & & & \\
\hline \multirow[t]{2}{*}{$\mathrm{DF}$} & $\mathrm{F}_{2}$ & -0.69 & 2.14 & -0.19 & -0.32 & 0.75 \\
\hline & $\mathrm{F}_{3}$ & 0.20 & 1.38 & 0.07 & 0.15 & 0.88 \\
\hline \multirow[t]{2}{*}{$\mathrm{DM}$} & $\mathrm{F}_{2}$ & 0.58 & 1.86 & 0.18 & 0.31 & 0.76 \\
\hline & $\mathrm{F}_{3}$ & 0.26 & 1.20 & 0.09 & 0.22 & 0.83 \\
\hline \multirow[t]{2}{*}{ PH } & $\mathrm{F}_{2}$ & 0.37 & 0.48 & 0.11 & 0.78 & 0.44 \\
\hline & $\mathrm{F}_{3}$ & 0.23 & 0.34 & 0.09 & 0.67 & 0.50 \\
\hline \multirow[t]{2}{*}{ PL } & $\mathrm{F}_{2}$ & 1.41 & 1.34 & 0.24 & 1.05 & 0.30 \\
\hline & $\mathrm{F}_{3}$ & -0.10 & 0.71 & -0.02 & -0.14 & 0.89 \\
\hline \multirow[t]{2}{*}{ PW } & $\mathrm{F}_{2}$ & -2.74 & 8.24 & -0.09 & -0.33 & 0.74 \\
\hline & $\mathrm{F}_{3}$ & 0.70 & 4.63 & 0.02 & 0.15 & 0.88 \\
\hline \multirow[t]{2}{*}{ ET } & $\mathrm{F}_{2}$ & -0.97 & 1.12 & -0.12 & -0.86 & 0.39 \\
\hline & $\mathrm{F}_{3}$ & 0.27 & 0.86 & 0.05 & 0.32 & 0.75 \\
\hline \multirow[t]{2}{*}{ FSP } & $\mathrm{F}_{2}$ & 0.26 & 0.50 & 0.29 & 0.51 & 0.61 \\
\hline & $\mathrm{F}_{3}$ & -0.30 & 0.62 & -0.38 & -0.49 & 0.63 \\
\hline \multirow[t]{2}{*}{ TSP } & $\mathrm{F}_{2}$ & -0.23 & 0.52 & -0.25 & -0.45 & 0.65 \\
\hline & $\mathrm{F}_{3}$ & 0.18 & 0.58 & 0.24 & 0.31 & 0.76 \\
\hline \multirow[t]{2}{*}{ TW } & $\mathrm{F}_{2}$ & 2.89 & 1.73 & 0.27 & 1.67 & 0.10 \\
\hline & $\mathrm{F}_{3}$ & -2.20 & 1.38 & -0.21 & -1.59 & 0.12 \\
\hline \multirow[t]{2}{*}{ GYP } & $\mathrm{F}_{2}$ & -0.73 & 0.83 & -0.17 & -0.88 & 0.38 \\
\hline & $\mathrm{F}_{3}$ & 0.43 & 0.72 & 0.11 & 0.60 & 0.55 \\
\hline \multirow[t]{2}{*}{ FLL } & $\mathrm{F}_{2}$ & -0.55 & 0.51 & -0.14 & -1.10 & 0.28 \\
\hline & $\mathrm{F}_{3}$ & 0.60 & 0.60 & 0.13 & 1.01 & 0.32 \\
\hline \multirow[t]{2}{*}{ FLW } & $\mathrm{F}_{2}$ & 33.08 & 16.75 & 0.26 & 1.97 & 0.05 \\
\hline & $\mathrm{F}_{3}$ & 14.17 & 18.76 & 0.09 & 0.76 & 0.45 \\
\hline
\end{tabular}

Only yield related traits viz., days to maturity, plant height, panicle length, number of effective tillers per plant, fertile spikelet per panicle and test weight were considered for pathcoefficient analysis (Table 4). The traits plant height, panicle length and test weight exhibited high positive direct effects on grain yield per plant in both $F_{2}$ and $F_{3}$. The high direct effects for above traits were also reported by Singh et al. (2013) for days to maturity, plant height, number of filled grains per panicle and test weight. The path coefficient analysis, thus, showed that plant height, panicle length, number of effective tillers per plant and test weight would exert a favourable direct influence on increased grain yield per plant, although the direct effect of above traits was high, this resulted in positive and significant correlation of these traits with grain yield per plant. The residual effect in $\mathrm{F}_{2}$ and $\mathrm{F}_{3}$ were moderate indicating that the traits considered for path analysis were appropriate. 
Table 4. Direct and indirect effect of six traits on grain yield per plant in $F_{2}$ and $F_{3}$ segregating generations of rice.

\begin{tabular}{llrrrrrrc}
\hline Traits & & DM & PH & PL & ET & FSP & TW & $\begin{array}{l}\text { Correlation } \\
\text { with GYP }\end{array}$ \\
\hline DM & $F_{2}$ & 0.084 & 0.057 & 0.048 & -0.003 & 0.028 & -0.063 & 0.151 \\
& $F_{3}$ & -0.178 & 0.050 & 0.025 & 0.042 & -0.006 & 0.034 & -0.033 \\
PH & $F_{2}$ & 0.021 & 0.228 & 0.024 & -0.011 & 0.001 & -0.043 & 0.220 \\
& $F_{3}$ & -0.033 & 0.268 & 0.044 & 0.024 & -0.017 & 0.031 & $0.318^{* *}$ \\
PL & $F_{2}$ & 0.013 & 0.017 & 0.315 & 0.005 & 0.009 & 0.091 & $0.450^{* *}$ \\
& $F_{3}$ & -0.034 & 0.091 & 0.130 & 0.139 & -0.008 & 0.020 & $0.338^{* *}$ \\
ET & $F_{2}$ & 0.002 & 0.018 & -0.010 & -0.141 & 0.007 & -0.087 & -0.212 \\
& $F_{3}$ & -0.017 & 0.014 & 0.040 & 0.451 & 0.017 & -0.053 & $0.453^{* *}$ \\
FSP & $F_{2}$ & 0.029 & 0.002 & 0.034 & -0.012 & 0.082 & -0.098 & 0.037 \\
& $F_{3}$ & -0.007 & 0.030 & 0.007 & -0.053 & -0.149 & 0.055 & -0.117 \\
TW & $F_{2}$ & -0.010 & -0.019 & 0.056 & 0.024 & -0.016 & 0.514 & $0.549 * *$ \\
& $F_{3}$ & -0.024 & 0.033 & 0.010 & -0.094 & -0.032 & 0.257 & 0.150 \\
\hline
\end{tabular}

The estimates of minimum number of genes controlling bacterial leaf blight resistance and yield related traits are presented in table 5. Estimation of number of genes becomes essential to carry out efficient selection in the segregating population. It is important to note that the estimation of number of genes is based on independent segregation; if loci are linked a large number will be involved (Parlevliet and Kupier 1985). The estimated gene number for bacterial leaf blight was 2.14 in the $F_{2}$ and 0.92 in the $F_{3}$ revealed that 2 genes were involved in the inheritance of resistance to bacterial leaf blight in $F_{2}$, while only one gene in $F_{3}$ due to dominance effect. The gene number for days to $50 \%$ flowering, days to maturity, plant height, number of effective tillers per plant, test weight, grain yield per plant and flag leaf length in the $F_{2}$ were 4.41 , $6.18,4.82,0.46,0.14,0.06$ and 1.62 respectively, whereas in the $\mathrm{F}_{3}$, the respective gene numbers were $0.24,0.22,1.68,0.07,0.09,0.22$ and 0.55 . The estimated number of genes for simply inherited traits viz., days to $50 \%$ flowering, days to maturity, plant height, number of effective tillers per plant, test weight, flag leaf length and disease severity were higher in $F_{2}$ in comparison to $\mathrm{F}_{3}$; unlike to those that have complex inheritance like grain yield per plant where estimated number of gene were higher in $\mathrm{F}_{3}$. Towey and Jinks (1977) postulated that the number of effective factors / genes increases steadily over successive generations of selfing following an initial cross. These results are conformity with the earlier reports of Alam et al. (2014).

Table 5. Estimation of minimum number of genes controlling bacterial leaf blight resistance and yield related traits in $F_{2}$ and $F_{3}$ segregating generations of rice.

\begin{tabular}{lccccccccc}
\hline & Generation & \multicolumn{10}{c}{ Traits } \\
\cline { 3 - 10 } & & DF & DM & PH & ET & TW & GYP & FLL & DS \\
\hline Estimated number & $\mathrm{F}_{2}$ & 4.41 & 6.18 & 4.82 & 0.46 & 0.14 & 0.06 & 1.62 & 2.14 \\
of genes & $\mathrm{F}_{3}$ & 0.24 & 0.22 & 1.68 & 0.07 & 0.09 & 0.22 & 0.55 & 0.92 \\
\hline
\end{tabular}

The present study revealed ample genetic variability was present in the segregating populations for yield related traits and bacterial leaf blight resistance. Further, high heritability for plant height, panicle length, panicle weight, number of effective tillers and grain yield per plant 
coupled with high genetic advance in segregating populations enhances possibility of selecting plants with superior grain yield and resistance, if selection is practiced for grain yield and resistance simultaneously. Rice is a strictly self pollinated crop so under above conditions, pedigree method of breeding would be the most convenient and effective breeding strategy to isolate high yielding pure lines with enhanced resistance of commercial value as advocated by Casali and Tigchelaar (1975). Several of the $F_{3}$ progenies were found superior to parents and thus identified as transgressive segregants. The $\mathrm{F}_{3}$ progenies, showing relatively low disease severity but had high grain yield per plant, could be further purified, multiplied and tested in station trials, may be used as donor parent to improve the bacterial leaf blight resistance and grain yield levels in existing rice cultivars.

\section{Acknowledgements}

Authors are thankful to U.P. Council of Agricultural Research, Lucknow, U. P., India for financial support through Grant No. P-26/75, B.H.U. Varanasi.

\section{References}

Ai-Jibouri HA, Miller PA and Robinson HF 1958. Genotypic and environmental variances and covariance in an upland cotton cross of interspecific origin. Agron. J. 50: 632-636.

Alam AM, Somta P and Srinives P 2014. Generation mean and path analyses of reaction to mungbean yellow mosaic virus (MYMV) and yield-related traits in mungbean (Vigna radiata (L.) Wilczek). SABRAO J. Breed. Genet. 46(1): 150-159.

Bjarko ME and Line RF 1988. Heritability and number of genes controlling leaf rust resistance in four cultivars of wheat. Phytopathol. 78: 456-462.

Casali VWD and Tigchelaar EC 1975. Computer simulation studies comparing pedigree, bulk and single seed descent selection in selfpollinating populations. J. Amer. Soc. Hort. Sci. 100: 364-367.

Channamallikarjuna V, Sonah H, Prasad M., Rao GJN, Chand S, Upreti HC, Singh NK, Sharma TR, 2010. Identification of major quantitative trait loci qSBR11-1 for sheath blight resistance in rice. Mol. Breed. 25: $155-166$.

Chouhan SK, Singh AK, Singh A, Singh SP, Singh NK and Singh PK 2014. Agro-morphological diversity in wild rice accessions of Eastern Indo-Gangetic region of India. Bangladesh J. Bot. 43(3): 337-344.

Dewey DR and Lu KH 1959. A correlation and path coefficient analysis of components of crested wheat grass seed production. Agron. J. 51: 515-18.

Fahy PC and Persley GJ 1983. Plant bacterial diseases: A diagnostic guide. Academic Press, New York. p. 393.

Gnanamanickam SS, Priyadarisini VB, Narayanan NN, Vasudevan P and Kavita S 1999. An overview of bacterial leaf blight disease of rice and strategies for its management. Curr. Sci. 77(11): 1435-1444.

Khush GS 2005. What it will take to feed 5 billion rice consumers in 2030. Plant Mol. Biol. 59: 1-6.

Loan LC, Du PV, Li Z 2004. Molecular dissection of quantitative resistance of sheath blight in rice (Oryza sativa L.). Omonrice 12: 1-12.

Oad FC, Samo MA, Hassan ZU, Pompe SC and Oad NL 2002. Correlation and path analysis of quantitative characters of rice ratoon cultivars and advance lines. Intl. J. Agric. Biol. 4(2): 204-207.

Panse VG and Sukhatme PV 1985. Statical methods for Agricultural workers. 4th ede. ICAR, New Delhi. p. 347.

Parlevliet JE and Kuiper HJ 1985. Accumulating polygenes for partial resistance in barley to leaf rust. Puccinia hordei, I. Selection for increased latent periods. Euphytica 34: 7-13.

Singh A. K., Nandan, R. and Singh, P. K. 2014b. Genetic variability and association analysis in rice germplasm under rainfed conditions. Crop Res. 47(1, 2 \& 3): 7-11. 
Singh, A, Singh AK, Parveen S and Singh PK 2013. Studies on genetic characteristic of upland rice (Oryza sativa L.). Int. J. Agric. Env. Biotech. 6(4): 515-520.

Singh A, Singh AK, Parveen S and Singh P K 2014a. Collection, agro-morphological characterization and assessment of variability in upland rice. Elect. J. Plant Breed. 5(3): 504-510.

Srinivasan B and Gnanamanickam S 2005. Identification of a new source of resistance in wild rice, Oryza rufipogon to bacterial leaf blight of rice caused by Indian strains of Xanthomonas oryzae pv. oryzae. Curr. Sci. 88: 1229-1231.

Towey P and Jinks JL 1977. Alternative ways of estimating the number of genes in a polygenic system by genotype assay. Heredity 39: 399-110.

(Manuscript received on 31 December, 2014; revised on 5 April, 2015) 